Krylova Iryna, PhD, Associate Professor of the Department of Business Economics, Mykolayiv National Agrarian University, Mykolayiv, Ukraine

ORCID ID: 0000-0002-2911-2474

e-mail: 2305irina@gmail.com

Ivanenko Tetiana, PhD, Associate Professor of Department of Hotel and Restaurant Business Organization, Mykolayiv National Agrarian University, Mykolayiv, Ukraine

ORCID ID: 0000-0003-0518-2563

e-mail: ivanenkotetiana84@gmail.com

Potochylova Iryna, Post-graduate student of the Department of Business Economics, Mykolayiv National Agrarian University, Mykolayiv, Ukraine

ORCID ID: 0000-0001-7785-4053

e-mail: potochilova@gmail.com

\title{
Demographic Component of Assessment of the Population Standard and Quality Of Life in the Concept of Human Development
}

\begin{abstract}
The essence of the economic category "quality of life" and "standard of living" is determined. The system of living standards recommended by the UN, the national matrix of quality of life indicators, the main international systems for assessing the population quality of life, the objective and subjective approach to its assessment are considered. The purpose of the study is to systematize indicators of the standard and quality of life of the population, the study of the demographic component of their assessment in the context of human development. It was found that today there is no single definition of "quality of life" (scientists supplement it based on the main purpose of their own research) and a single approach to its evaluation. It is determined that among the various methods and approaches to assessing the use of demographic indicators is quite limited. The characteristic of the basic demographic indicators which can be applied in research both standard and quality of life of the population is given. The main demographic indicators of measuring the quality of life of the population in Ukraine and in Mykolayiv region are determined and analyzed.

Keywords: quality of life, standard of living; indicators; demographic characteristics; subjective assessments; objective assessments; natural decrease; life expectancy; birth rate; mortality.
\end{abstract}

\section{УдК 314.1:330.59}

Крилова I. Г., кандидат економічних наук, доцент кафедри економіки підприємств Миколаївського національного аграрного університету, м. Миколаїв, Україна

Іваненко Т. Я., кандидат економічних наук, доцент кафедри готельно-ресторанної справи та організації бізнесу Миколаївського національного аграрного університету, м. Миколаїв, Україна

Поточилова I. C., аспірант кафедри економіки підприємств, Миколаївський національний аграрний університет, м. Миколаїв, Україна

\section{Демографічна складова оцінки рівня і якості життя населення в концепції людського розвитку}

Анотація. Основою розвитку будь-якої країни або суспільства є людина та ї̈ добробут. Зростання всіх видів національного багатства, накопичення суспільством матеріальних та духовних цінностей без участі людини неможливе. Наскільки людина в сучасному суспільстві може відчувати себе в безпеці, якою мірою рівень ї̈ життя може гарантувати його якість - всі ці питання завжди є актуальними. Рівень життя найчастіше означає ступінь задоволення матеріальних, духовних і соціальних потреб населення і є результатом розподілу створених у суспільстві благ. У порівнянні з економічної категорією «якість життя» значно вужча, оскільки не враховує усі сторони людського існування.

Метою дослідження $\epsilon$ систематизація показників рівня та якості життя населення, дослідження демографічної складової їх оцінки в контексті людського розвитку та аналіз основних демографічних показників якості життя Миколаївської області та України.

Визначено сутність економічної категорії «якість життя» та «рівень життя». Розглянуто систему показників рівня життя, рекомендовану ООН, національну матрицю індикаторів якості життя, основні міжнародні системи оцінки якості життя населення, об'єктивний та суб'єктивний підхід щодо його оцінювання. З'ясовано, що сьогодні не існує єдиного визначення поняття «якість життя» (науковці доповнюють його, виходячи з основної мети власних досліджень), крім того, не існує і єдиного підходу щодо його оцінки. Визначено, що серед різних методик і підходів оцінки використання демографічних показників достатньо обмежене. 
Соціально-економічний розвиток краӥни грунтується на поліпшенні якості життя населення, підвищенні його рівня. Вважаємо, що в їх інтегральній оцінці важливою складовою є саме демографічна, адже демографічні процеси можуть бути як наслідком (результатом) якості життя, такі впливовим фактором. Демографічна ситуація в країні надзвичайна складна: відсутність природного приросту населення; висока передчасна смертність, при значному рівні старіння населення; незмінна структура причин смертності (найбільша питома вага померлих внаслідок хвороб системи кровообігу та новоутворень); низька народжуваність; звужений режим відтворення покоління матерів; сумарний показник народжуваності не свідчить про забезпечення простого відтворення населення. Отже, підсумовуючи зазначимо, що об'єктивні, кількісні демографічні показники не свідчать про поліпшення якості життя населення України (Миколаївської області).

Ключові слова: якість життя; рівень життя; показники; демографічні характеристики; суб'єктивні оцінки; об'єктивні оцінки; природне зменшення; тривалість життя; народжуваність; смертність.

Formulation of the problem. The basis for the development of any country or society is a person, its wellbeing. The growth of all types of national wealth, the accumulation of material and spiritual values by society without human participation is impossible. In the XXI century, it is human capital that acquires the most significant influence among all the components of the country's national wealth.

So, the main condition for the country's human development is to improve the quality and standard of living of the population. In turn, the quality of life implies expanded opportunities for a person in all spheres of his life. The main idea of the concept of human development is to increase human capabilities, which is ensured by political freedom, human rights, and public respect for the individual. How many persons in modern society can feel safe and protected, to what extent their standard of living can guarantee its quality - all these questions will undoubtedly always be relevant.

Analysis of recent research and publications. Prominent scientists studied the problems of assessing the level and quality of life of the population: E. Libanova (characteristics of the human potential of the population, demographic components of human development), O. Gladun (assessment of the formation of human capital, demographic research), S. Aksenova (demographic measurement of the quality of life of the population), O. Grishnova (human capital, demographic research) and many others. The main theoretical and applied developments regarding the quality of the population belong to such researchers as J. Becker, J. A. Birdmore, G. Doug, L. Jorgenson, P. Cox, F. Hauser, T. Schultz, and others.

Their scientific achievements are valuable for studying this problem in the current economic conditions of the development of a socially-oriented economy of the country. However, the issues of research and evaluation of the main factors in the formation of the level and population quality of life in demographic terms remain relevant.

Formulation of research goals. The aim of the study is to systematize indicators of the level and quality of life of the population, to study the demographic component of their assessment in the context of human development. The analysis of the main demographic indicators of the quality of life in the Mykolayiv region and Ukraine is done.

Outline of the main research material. In 1990, the UN report on human development was first published, where it was determined that the main goal of social progress is to ensure the expansion of opportunities for: a long, healthy and creative human life, access to education and knowledge accumulated by mankind, and personal freedom.

According to ILO conventions, everyone has the right to such a standard of living (including food, clothing, housing, medical care, social services) as is necessary to maintain their health and well - being, as well as the right to unemployment insurance, disability, loss of breadwinner. In each country, these rights are implemented on the basis of the National concept of the standard of living. The standard of living often means the degree of satisfaction of material, spiritual and social needs of the population and is the result of the distribution of goods created in society. The standard of living as an economic category has been used in UN research since 1961. Compared to the economic category "quality of life", it is much narrower, since it does not take into account all aspects of human existence.

The standard of living is a dynamic process that is influenced by many factors. The dynamics of living standards indicate the results of the country's economic development, as well as the degree of socialization of the economy. The main indicators of the state of the economic system that determine the conditions for the formation of the standard of living in the country are as follows: the value of gross domestic product per capita; the volume of gross domestic product; the Consumer Price Index; the share of wages of employees in GDP; the share of final consumer expenditures of households in GDP; the volume of retail trade turnover (per person); the ratio of food and non-food products in retail trade; the level of participation of the population in the labor force; the size of the wage fund per employee (nominal, real); the coefficient of demoeconomic capacity; the ratio of the minimum pension and minimum wage of employees employed in the economy; the number of small enterprises (per 10 thousand population); the obligations of banks for funds raised to the accounts of individuals; the unemployment rate; the discount rate of the NBU.

The system of indicators of the standard of living recommended by the UN includes 12 sections: demographic characteristics; sanitary and hygienic living conditions; food consumption; housing conditions of the population; education and culture; employment and working conditions; income and expenses; cost of living 
and consumer prices; vehicles; organization of recreation; social security; human freedom.

In the system of determining the standard of living of the population, income indicators occupy a central place as the main source of meeting personal needs for goods, services and improving the level of well-being. In the concept of human development, income indicators of the population are used as a measure of control over resources. The level of income gives an idea of the material capabilities of people. The average per capita income reflects the inclusion degree of residents of a particular state in the world of social relations (access to information, ability to travel, relax, communicate with family and friends, buy and equip housing, visit theaters, museums).

Income growth is one of the means of empowering people and increases their welfare. But income is not a measure of human happiness. It is not enough to meet many urgent needs that go beyond material well-being. What determines the relationship between wealth accumulation and human development is not so much the rate of wealth growth as how it is used by people.

The main ideas of the concept of quality of life were developed in research on the strategy of human development in the 70s of the Twentieth century. The economic and Social Council of the United Nations (ECOSOC) systematized and summarized the proposals of demographers, sociologists, economists, environmentalists and specialists of other profiles, and prepared a document on the strategy for further human development [3, P.12]. There is currently no single and approved definition of the concept of "quality of life" (as well as a single approach to its assessment), scientists supplement the meaning of this concept based on their own research goals. Among the main subsystems of quality of life, the following can be distinguished: quality of public life, quality of working life, quality of family life, quality of personal life. Without a doubt, all subsystems are significantly influenced by economic, political, social, and environmental factors. We agree with the opinion that the quality of life is a complex integral socioeconomic category that studies the physical, psychological, material and social well-being of the population, as well as the conditions for their provision [1, p. 58].

The world scientific and academic community applies the general methodological concept of standards and quality of life to assess social progress in different countries, where, in the principle of calculation, there is a distinction between macroeconomic indicators and sociological indicators. The following indicators are used: GDP per person, Consumer Price Index, consumer basket, GFK basket, government spending, poverty level, income inequality and subjective indicators (life satisfaction and happiness, derivation, optimism about the future, etc.). International Assessment Systems also include the following: EU methodology European Statistical System Committee, International Living Quality Index, European quality of life monitoring, Better Life Initiative (OECD). The European Statistical System Committee (European Statistical System Committee) the principle of assessment is to take into account quantitative and subjective indicators: material and living conditions, productive or basic activity, health, education, leisure and Social Communications, economic and physical security, public administration and fundamental rights, nature and environment, general perception of life. The International Living Quality of Life Index (which defines the Journal of the same name) includes the following indicators: cost of living, culture, economy, environment, freedom, health, infrastructure, safety and risk, climate (generally equivalent to taking into account quantitative and subjective indicators). The European quality of life monitoring conducts a sociological survey of the quality of life (based on subjective assessments) based on the following indicators: health, employment, income indicators, education, family, social participation, housing, environment, transport, security, recreation, life satisfaction. The Better Life Initiative conducts an integral assessment of the following parameters: housing conditions, income, employment, education, ecology, health, management efficiency, public life, safety, satisfaction with living conditions, balance between working time and leisure [2, p. 10].

In Ukraine, when forming the National matrix of quality of life indicators, it is proposed to distinguish three blocks (subjective assessment, condition, current situation) and four environments: natural, social, economic, socio-political. At the same time, the last three environments have their own sub-environments: ecology; health; education; security; culture, art, recreation; housing; transport; economy; employment; social activity; public environment. Thus, The Matrix has thirty-three structural elements, while the structural element consists of a certain number of indicators [2, p. 24].

As noted earlier, no single methodological approach has been developed to determine the main components of the quality of life of the population. But, in general, we can distinguish an objective and subjective approach to assessing the quality of life of the population [2, p. 7]. A significant difference between the two is the source of data for evaluation. An objective approach (which is the most common) makes it possible to determine the quality of the social and physical (artificial and natural) environment in which people try to actualize their needs. At the same time, objective parameters for assessing the quality of life are measured using methods that do not depend on the appraiser's attitude to the properties of the object of measurement and are aimed at obtaining values in standardized units of measurement. An objective assessment of economic factors of quality of life covers indicators of material well-being, average per capita income; average monthly salary, the size of the subsistence minimum, the number of people with incomes below the subsistence minimum, the structure of monetary income and expenses of the population (Index 
Gini); Housing Security, etc. So, the source of objective indicators is state statistics and special observations conducted by specialized institutions.

The subjective approach involves determining the quality of life on the basis of sociological surveys (specially organized sample surveys of the population). Subjective assessments reflect an individual's perception of the quality of life and are based on subjective feelings and personal assessments. Most researchers distinguish rational (overall life satisfaction, assessment of the degree of satisfaction with various aspects of life) and emotional components (balance of positive and negative emotions) in subjective assessments.

The main theoretical and methodological approaches to assessing the quality of life cover the economic, social dimension and the concept of subjective well-being. From the point of view of the economic dimension, the main emphasis is placed on the fact that the higher a person's income, the more they can meet their needs and get what they want, therefore, this leads to an improvement in their quality of life. The social approach is based on assessing the quality of life using social indicators, which, unlike subjective self-assessments, are objective quantitative indicators. The most common social indicators are indicators of crime, education, ecology, and protection of citizens' rights and freedoms. According to this measurement, factors such as feelings of happiness and satisfaction have a greater impact than objective indicators, and the measurement of quality of life has shifted from objective indicators to a person's subjective assessment of its life and its various aspects [1, p. 60]. It should be noted that the calculation of objective indicators in different countries has its own methodological features, while the assessment of subjective well-being on a single scale makes it possible to conduct international comparisons on a single methodological basis.

Table 1 Main demographic indicators for measuring the quality of life of the population

\begin{tabular}{|c|c|}
\hline Indicator & Characteristic \\
\hline \multicolumn{2}{|r|}{ Birth rate } \\
\hline $\begin{array}{l}\text { Net indicator of } \\
\text { reproduction rate of the } \\
\text { female generation }\end{array}$ & $\begin{array}{l}\text { shows the average number of girls, who were born to one woman during their lifetime, would have lived } \\
\text { to the age of their mother at their birth, provided that the available birth and mortality rates are } \\
\text { maintained at each age. }\end{array}$ \\
\hline The total birth rate & $\begin{array}{l}\text { determines how many children one average woman would give birth to, during the entire reproductive } \\
\text { period ( } 15-49 \text { years) if each age kept the birth rate in the year for which the age coefficients are } \\
\text { calculated (to ensure simple reproduction of the population, it is necessary that the indicator was at the } \\
\text { level of } 2.1 \text { children per woman) }\end{array}$ \\
\hline $\begin{array}{ll}\begin{array}{l}\text { Natural } \\
\text { (reduction) }\end{array} & \text { growth } \\
\end{array}$ & $\begin{array}{l}\text { shows the excess of birth rates over mortality and characterizes the ability of the population to change } \\
\text { its size and maintain balance }\end{array}$ \\
\hline $\begin{array}{l}\text { Adolescent birth rate } \\
\text { (15-17 or } 15-19 \text { years) }\end{array}$ & $\begin{array}{l}\text { characterizes the intensity of childbearing of women of the youngest reproductive age; age-related birth } \\
\text { rates are calculated as the ratio of the number of children born during a certain period (most often, a } \\
\text { year) by women of a certain age group to the average annual number of women at this age }\end{array}$ \\
\hline $\begin{array}{l}\text { Average age of the } \\
\text { mother at the birth of a } \\
\text { child (first child) }\end{array}$ & $\begin{array}{l}\text { calculations are made on the basis of birth rates for one-year-old age groups, most often analyzed the } \\
\text { average age of motherhood for the entire population of newborns and separately for children of the } \\
\text { first order of birth }\end{array}$ \\
\hline \multicolumn{2}{|r|}{ Mortality rate } \\
\hline $\begin{array}{l}\text { The rate of premature } \\
\text { mortality }\end{array}$ & $\begin{array}{l}\text { is calculated as the ratio of the number of deaths in the range of } 0-64 \text { years during a calendar year to } \\
\text { the average annual population of the corresponding age, multiplied by } 100,000\end{array}$ \\
\hline \multicolumn{2}{|r|}{ Health and life expectancy } \\
\hline Life expectancy at birth & $\begin{array}{l}\text { the average number of years, that a newborn can live, on conditions for maintaining, during his later life, } \\
\text { the age-related mortality regime that is currently observed }\end{array}$ \\
\hline $\begin{array}{l}\text { Life expectancy at the } \\
\text { age of } 65\end{array}$ & $\begin{array}{l}\text { measures the number of years that a person can live, after reaching the age of } 65 \text {, if the current age } \\
\text { characteristics of mortality remain }\end{array}$ \\
\hline $\begin{array}{l}\text { Self-assessment of } \\
\text { health }\end{array}$ & the proportion of people who rated their health status as good or very good \\
\hline $\begin{array}{l}\text { The expected duration } \\
\text { of a (relatively) healthy } \\
\text { life at the age of } 20 \text { and } \\
65\end{array}$ & $\begin{array}{l}\text { is interpreted as the period of life with a good or satisfactory state of health, determined on the basis of } \\
\text { self-assessments of the state of health, that is, the subjective characteristics of respondents }\end{array}$ \\
\hline
\end{tabular}

Source: processed by researcher [1,4]

Consideration of the main approaches and methods for assessing the quality of life of the population proves that the use of demographic indicators is quite limited. Note that demographic processes significantly affect the quality of life of the population. At the same time, it is desirable to consider demographic indicators in conjunction with such indicators that have a significant impact on demographic processes in the country: employment, unemployment, education, income level. It is noted that to fully assess the demographic component of the quality of life, it is necessary to analyze the indicators of marriage and family relations, because the 
quality of family relations significantly affects the selfassessment of a person's life, well-being and development.

The proposed methodological scheme for studying the standard of living of the population of Ukraine provides three main blocks: assessment of the financial situation of the population; characteristics of the living conditions of the population and research of the state of the social environment. At the same time, the block "state of the social environment" provides for determining the following demographic indicators: the ratio of marriages and divorces, the share of those born out of wedlock, the share of early births, the number of abortions per 100 live births, the share of deaths from exogenous causes in the total number of deaths, the number of suicides (per 100,000 population), the share of premature deaths in the total number of deaths, the mortality rate of the population from neoplasms (per 100,000 population) [3,p. 29, p.47].

Table 2 Dynamics of the main demographic indicators of the Mykolayiv region and Ukraine

\begin{tabular}{|c|c|c|c|c|c|c|}
\hline \multirow[b]{2}{*}{ Indicators } & \multicolumn{2}{|c|}{1991} & \multicolumn{2}{|c|}{2000} & \multicolumn{2}{|c|}{2019} \\
\hline & $\begin{array}{l}\text { Mykolayiv } \\
\text { region }\end{array}$ & Ukraine & $\begin{array}{l}\text { Mykolayiv } \\
\text { region }\end{array}$ & Ukraine & $\begin{array}{l}\text { Mykolayiv } \\
\text { region }\end{array}$ & Ukraine \\
\hline Natural growth (reduction), persons & +311 & -39147 & -9920 & -372956 & -9121 & -272297 \\
\hline Depopulation coefficient & 0,98 & 1,06 & 1,97 & 1,97 & 2,14 & 1,88 \\
\hline Total birth rate, per 1 woman & 1,850 & 1,776 & 1,121 & 1,116 & 1,119 & 1,228 \\
\hline $\begin{array}{l}\text { Net reproduction rate of the female } \\
\text { generation, per } 1 \text { woman }\end{array}$ & 0,873 & 0,842 & 0,526 & 0,526 & 0,537 & 0,584 \\
\hline $\begin{array}{l}\text { Adolescent birth rate } 15-19 \text { years } \\
\text { (per } 1000 \text { women) }\end{array}$ & 75,8 & 60,3 & 40,0 & 32,1 & 20,6 & 16,9 \\
\hline \multicolumn{7}{|c|}{ Average life expectancy at birth (years): } \\
\hline - both sexes & 68,44 & 69,56 & 65,87 & 67,72 & 71,32 & 72,01 \\
\hline - men & 63,23 & 64,62 & 60,10 & 62,10 & 66,26 & 66,92 \\
\hline - women & 73,59 & 74,21 & 72,02 & 73,53 & 76,26 & 76,98 \\
\hline \multicolumn{7}{|c|}{ Average life expectancy at the age of 45 Years ( Years): } \\
\hline - both sexes & 28,22 & 28,94 & 26,78 & 27,56 & 29,94 & 30,28 \\
\hline - men & 24,37 & 25,19 & 22,61 & 23,36 & 25,81 & 26,04 \\
\hline - women & 31,62 & 32,04 & 30,70 & 31,41 & 33,52 & 34,06 \\
\hline \multicolumn{7}{|c|}{ Average life expectancy at the age of 65 years (years): } \\
\hline - both sexes & 14,05 & 14,26 & 13,27 & 13,68 & 15,17 & 15,26 \\
\hline - men & 11,97 & 12,14 & 11,16 & 11,49 & 12,69 & 12,70 \\
\hline - women & 15,23 & 15,39 & 14,65 & 15,39 & 16,80 & 16,98 \\
\hline
\end{tabular}

Source: processed by researcher $[4,5,6]$

The current demographic situation both in the whole country and in the Mykolayiv region is extremely difficult. The last population growth in Ukraine was recorded in 1990, in the region in 1991 . The depopulation coefficient is more than the limit value (1), for example, in Mykolayiv area during 2019 the birth rate was lower than the mortality in 2 times, and as a whole across the country for the same period $88 \%$ more. The net rate of reproduction of the female generation is less than one, therefore, there is a narrowed reproduction of the generation of mothers; the number of births decreases. To ensure simple reproduction of the population, it is necessary that the total fertility rate was at the level of 2.1 children per woman. For the period 1991-2019, this indicator (both in the Mykolayiv region and in Ukraine) was lower than this level. It is noted that our research aimed at linking feelings of happiness and reproductive intentions has found that happy people are more likely to have another child than others. [1, P. 65]. It should be noted that the decline in adolescent births, the highest level was observed in 19911992 at the level of 60.5 (at the same time, in the Mykolayiv region, this indicator during the study period is higher than the national average). The growth of this indicator causes public concern and cannot indicate an improvement in the quality of life of the population. After all, the birth rate of women under the age of 20 increases their socio-economic risks in the future: it limits their opportunities in school, career, and affects the level of income. But it should be noted that the childbearing activity of Ukrainian women in adolescence is significantly higher than in developed European countries, which have the best rating in terms of quality of life.

An important demographic indicator for assessing the quality of life is the average age of the mother at birth. In Ukraine, there is an increase in the average age from 24.7 years in 1991 to 27.7 years in 2018, the average age of a mother at the birth of her first child in 2019 is 26.2 years, while, for example, in 2018, 25.4 years [1 P. 69, 9 p.105]. Postponing motherhood to an older age characterizes the expansion of opportunities for women associated with her self-realization and career. The highest mean age of childbearing was found in Australia and New Zealand (30.8 years) and in Europe and Northern America (29.8 years). $[7$, p. 2] 
An important demographic problem is the premature mortality of the population in Ukraine, and life expectancy is significantly lower than in European countries. At the same time, the life expectancy of men due to biological and behavioral factors is less than that of women. It should be noted that the indicators of the average life expectancy of the population in Mykolayiv region are lower than the national average.

Conclusions. Conclusions from the study. Socioeconomic development of the country is based on improving the quality of life of the population, increasing its level. It was found that today there is no single definition of "quality of life" (scientists supplement it based on the main goal of their own research) and a single approach to its assessment. It is determined that among various assessment methods and approaches, the use of demographic indicators is quite limited. We believe that the demographic component is an important component in their integral assessment. After all, demographic processes can be both a consequence, a result of the quality of life, and an influential factor. The demographic situation in the country is extremely complex: lack of natural population growth; high premature mortality, with a significant level of population aging; unchanged structure of causes of death (the largest share of deaths due to diseases of the circulatory system and neoplasms); low birth rate narrowed reproduction mode of the mother generation; the total birth rate does not indicate ensuring simple reproduction of the population. So, summing up, we note that objective, quantitative demographic indicators do not indicate an improvement in the quality of life of the population of Ukraine (Mykolayiv region).

\section{References:}

1. Gladun, O. M. (Eds.) (2019). Naselennya Ukraïni. Demografichnij vimir yakosti zhittya. Kyiv: Ptoukha Institute for Demography and Social Studies of the National Academy of Sciences of Ukraine [in Ukrainian].

2. Libanova, E. M., Gladun, O. M. \& Lisogor, L. S. and etc. (2013). Vimiryuvannya yakosti zhittya v Ukraïni. Kyiv: Ptoukha Institute for Demography and Social Studies of the National Academy of Sciences of Ukraine [in Ukrainian]

3. Cherenko, L. M. (Eds.) (2006). Riven zhittya naselennya Ukraïni. Kyiv: Konsultant [in Ukrainian].

4. State Statistics Service of Ukraine (2019). Naselennya Ukraïni za 2019 rik. Retrieved from http://www.ukrstat.gov.ua/druk/publicat/kat_u/2020/zb/10/zb_nas_2019.pdf [in Ukrainian].

5. State Statistics Service of Ukraine (2020). Statistika naselennya Ukraini. Official web-site. Retrieved from http://database.ukrcensus.gov.ua/Mult/Dialog/statfile_c.asp.

6. State Statistics Service of Ukraine. Official web-site. Retrieved from http://www.ukrstat.gov.ua [in Ukrainian].

7. Golovne upravlinnya statistiki u Mikolaïvskij oblasti. Official web-site. Retrieved from http://www.mk.ukrstat.gov.ua [in Ukrainian]

8. United Nations \& Population Division of the United Nations Department of Economic and Social Affairs (2019). Potential impact of later childbearing on future population. Population Facts, 5. Retrieved from: https://www.un.org/en/development/desa /population/publications/pdf/popfacts/PopFacts_2019-5.pdf.

9. Grishnova, O. A. \& Harazishvili, Yu. M. (2019). Demografichna bezpeka Ukraïni: indifikatori, riven, zagrozi. Demography and social economy, 2 (36), 65-80. doi: https://doi.org/10.15407/dse2019.02 [in Ukrainian]

10. Gladun, O. M. (Eds.) (2015). Naselennya Ukraïni: demografichniskladovi lyuds'kogo rozvitku. Uman: Sochinsky [in Ukrainian].

11. Libanova, E., Osaulenko, O. \& Cherenko, L. (2020) Otcinka yakosti zhittya v Ukraïni na osnovi sub'ektivnih pokaznikiv dobrobutu. Warsaw: RS Global Sp. z O.O.

12. Ptoukha Institute for Demography and Social Studies of the National Academy of Sciences of Ukraine (2014). Naselennya Ukrayini. Imperativi demografichnogo starinnya. Kyiv: ADEF-Ukrayina [in Ukrainian].

13. State Statistics Service of Ukraine (2020). Samoocinka naselennyam stanu zdorov'ya ta rivnya dostupnosti okremih vidiv medichnoï dopomogi u 2019 roci. Statistichnij zbirnik. Kyiv [in Ukrainian].

14. Cannas, M., Sergi, B. S., Sironi, E. \& Mentel, U. (2019). Job satisfaction and subjective well-being in Europe. Economics and Sociology. 2019. 12 (4), 183-196. doi: https://doi.org/10.14254/2071-789X.2019/12-4/11. 